\title{
Agency Mindset Theory
}

Maurice Yolles (prof.m.yolles@gmail.com)

Gerhard Fink (Gerhard.Fink@wu-wien.ac.a)

July, 2013

\begin{abstract}
A culturally based socio-cognitive agency generic model is developed. The agency has a normative personality with an values/beliefs indicated by its formative traits. These can take bi-polar epistemic values ("enantiomers"). These may be combined together, giving 8 different cognitive types that are personality type mind-sets. These types are influenced by the culture and the social environment that the agency is bound to. The traits can be used to explain the what, why and how of dynamic agency behaviour in complex situations.
\end{abstract}

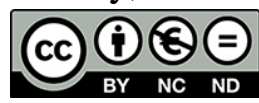

Keywords: socio-cognitive, agency, generic model, mind-sets.

\section{Modelling Agency and its Normative Personality}

The generic model that we shall develop is concerned with the plural agency which has as part of its structure a "collective mind" that is constituted as a normative personality. Our interest lies in recognising that the personality norms that arise in a plural agency arise from a stable collective. These norms act as a basis from which a unitary cognitive structure coalesces such that a collective mind can be inferred, and from which an emergent normative personality arises. To explain this further, consider that stable plural agencies develop a common dominant culture within which shared beliefs develop in relation to the capacity of the collective to produce desired outcomes. Cultural anchors are created that are represented within the paradigm that the agency carries and which makes it durable. This enables the development of formal and informal norms for patterns of behaviour, modes of conduct and expression, forms of thought, attitudes and values that are more-or-less adhered to by its membership.

Figure 1 is a generic/meta model. It adopts a set of generic conceptual characteristics of living systems (Yolles, 2006). It comes from Schwarz's (2003) "Living System Theory" that describes the dynamics of more or less complex entities defined as sets of several (at least two) interacting parts. His starting point consists of identifying three inseparable primal categories present in all systems: objects, relations and wholes. Here, these three types of initial ingredients are on equal footing. In his meta-model he argues that he has an extension of the mechanist paradigm where objects have a privileged ontological status. In his new paradigm of ultimate "reality" (that which exists), there are two complementary, inseparable and irreducible aspects: objects and relations.

Figure 1 is bedded on recursive principles of systemic hierarchy: where systems are structured as a hierarchically nested set of recursively embedded systems, one within another creating more complexity in the modelling process (Williams and Imam, 2006). Thus, complex "bottom-up" interpersonal interrelationships can be modelled through a complex multiplicity of reasons. These reasons are often are taken as a principle of emergence that "cause" higher order systemic forms in which complexity becomes reduced to an invisible horizon of meanings. Under normal circumstances, through legitimization of selected patterns of action top-down influences, the nature of the interactions at the bottom level can be constrained. Such constraints through legitimization may be ineffective in post-normal 
situations (those experiencing uncertainty such that they may be at the edge of stability), especially if they lead to crisis (Dempster, 1999; Tognetti, 1999). Thus, the modelling approach can represent networks of processes at the individual and small group level, as well as their impact on the higher level social influence networks of processes and vice versa (Yolles, 2006).

Figure 1 also shows five formative traits in any agency, one of which defines its cultural orientation, 3 of which define its normative personality (the cognitive, figurative, operative orientations), and the last of which defines its social orientation which emerges through interaction with the social environment. The normative personality traits have been discussed at length in Yolles \& Fink (2013). As indicated by Yolles, Fink and Dauber. (2011) and Fink, Dauber and Yolles (2012), in the context of organizational culture research, traits are bi-polar value dimensions that typify agency and establish a basis for strong anticipation. It is through these bi-polar traits that agency and indeed personality orientation preferences can be indicated in the respective domains - for the forward linkages (i.e. action oriented processes) or feedback linkages (i.e. information collection, adaptation and learning processes). The anticipation of patterns of behaviour is possible knowing sufficient about the traits, which function as personality control variables (Van Egeren, 2009).

For Fleishman, Constanza \& Marshall-Mies (1999) traits are also related to performance. In corporate theory the traits have generic characteristics that are domain dependent, and may be seen as normative personality variables that regulate the importance attributed to different classes of information. They are indicative of personality styles that arise from personality types. Types have a special role in personality theory. They are deemed to be responsible for the patterns of behaviour that a personality generates, and since behaviour is closely related to cognitive structure which it facilitates and constrains, so traits are also connected with personality structure. Patterns of behaviour are generically defined as an abstraction from a concrete form that keeps on recurring in specific, non-arbitrary contexts. It is this very nature that enables an agency's behaviour to be strongly anticipated, even when it comes to their interaction with personal and situational variables.

The conceptual model of Figure 1 has special transitive functions that cut across distinct ontological systems through an autogenetic ${ }^{1}$ (or figurative) conduit through which the laws are generated by which the agency operates, and an autopoietic ${ }^{2}$ (or operative) conduit through which operative relationships are generated (Schwarz, 1997). These generations are facilitated through the conduits by a number of transitive intelligences. Of these, Piagetian intelligences play a substantive part (Yolles et al., 2011), as do cultural and emotional intelligence. These intelligences may be seen as a network of relational processes of transformation of a definable set of components of a given domain of the living system that: (i) through their interactions and transformations, continuously regenerate, realize and adapt the relations that produce them; and (ii) constitute its socio-cognitive nature as a concrete unity.

For Piaget (cited in Elkind, 1976: 56), intelligence is something that creates an internal connective orientation within an agency (or its personality) towards its environment. This orientation is connected to the capacity of the agency to adapt (Piaget, 1963, pp. 3-4, cited in Plucker, 2012). The Piagetian (1977) intelligences include operative intelligence, which frames how the world is understood and where understanding is unsuccessful operative intelligence changes, and figurative intelligence, which is a form of autogenesis (Schwarz, 
1997; Yolles, Fink Dauber, 2011) that provides core relational explanations of reality as a reflection of patterns of knowledge.

Operative intelligence is concerned with the representation and manipulation of the transformational aspects of reality, and involves all actions that are undertaken so as to anticipate, follow or recover the operative transformations. It also refers to highly integrated and generalised sets of actions that are adaptive in nature (Schoenfeld, 1986). It can thus be thought of as the effective capacity to create a cycle of activity that operatively manifests schemas. There are two forms of operative intelligence illustrated in Figure 1: one is connected with the agency as a whole, and the other with its normative personality, and both have similar functions. Personality operative intelligence manifests strategic schemas from the figurative system to the operative system. It creates rules. Agency operative intelligence manifests agency schemas from the personality as a whole to the agency operative system. While both personality and agency operative intelligences are constituted as a network of self-producing processes, in the agency they involve hierarchy and bureaucracy, which is responsible for the implementation of policy that arises from the normative personality.

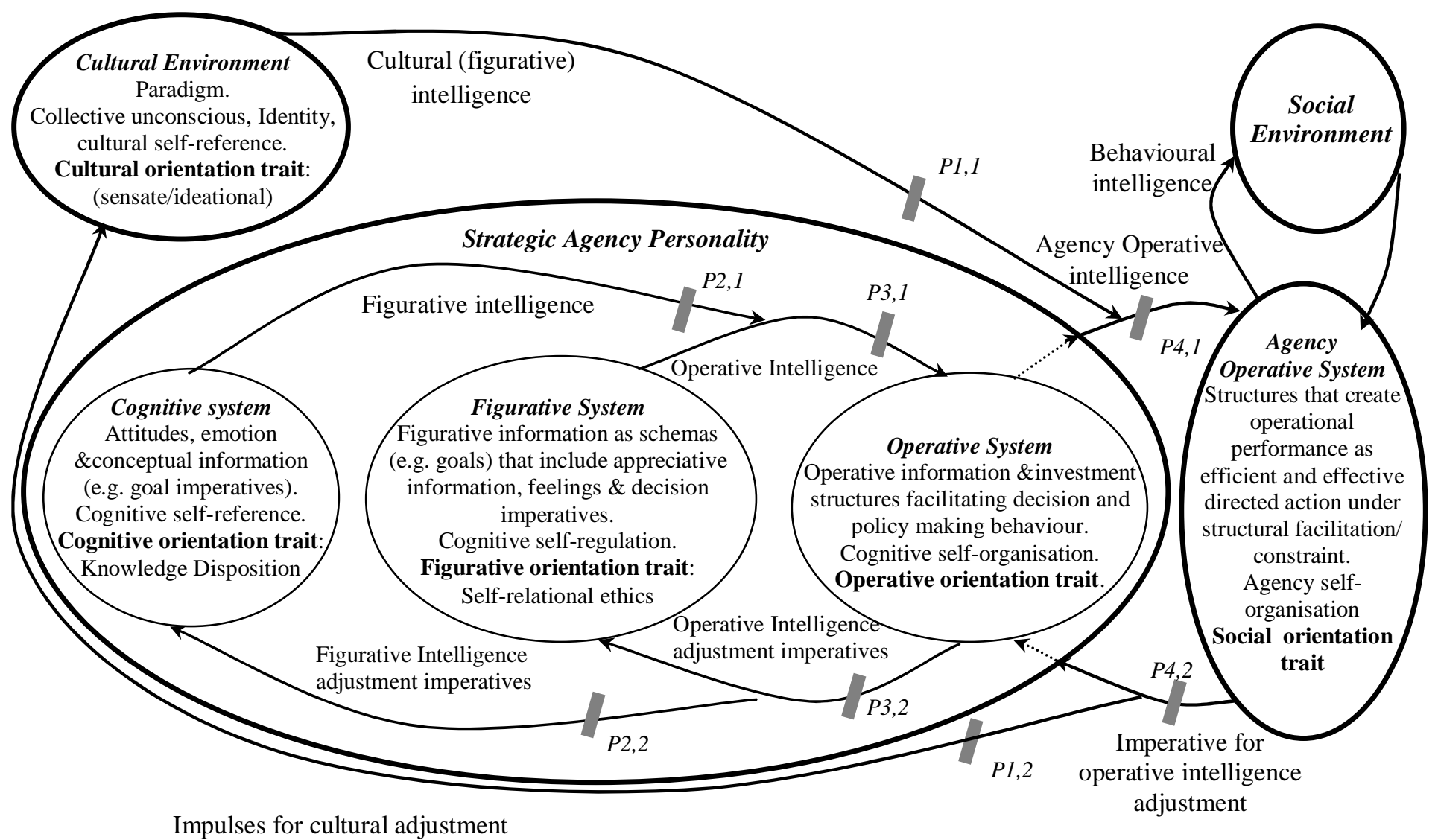

Note:Pi,j (where pathology type $i=1,4$ and order $j=1,2$ ) refers to type-pathologies that can arise through both intelligence limitation and impeded efficacy

Figure 1: A Relational “Living System” meta-model of an Agency in Interaction with its Environments

Figurative intelligence manifests knowledge as information about states of reality, which it delivers to the figurative system to enable perception, drawing, mental imagery, language and imitation (Montangero \& Maurice-Naville, 1997; Piaget, 1950; Piaget \& Inhelder 1969). There are two forms of figurative intelligence indicated in Figure 1: cultural (figurative) 
intelligence and personality figurative intelligence. Cultural (figurative) intelligence is used when knowledge is manifested from agency culture to the cognitive system in the personality as conceptual information, which serves to attract the attitudes and values of the normative personality to those of the cultural environment. Through figurative intelligence within the personality, this information is then manifested as a variety of strategic forms of schemata like goals, ideology, ethics, and self-scripts. Self-scripts connect strategic expectations with operative structure and behaviour.

Behavioural intelligence influences how policy developed by personality is implemented. It occurs as a "structural coupling" that represents a simple interaction between two (or more) living systems (i.e., a behavioural system and its environment consisting of other behavioural systems). The interrelations maintain a past and future relationship between the agency operative system and that of interactive others.

The autopoietic conduit is also used by the agency (Figure 1) in order to become efficacious in the generation of operative performance. In the plural agency, this is normally referred to as collective efficacy. Lindsley, Brass \& Thomas (1995) citing Guzzo, Yost, Campbell, \& Shea (1993: 9) note that efficacy is a task specific potency that is meant to refer to a shared belief about general effectiveness across multiple tasks encountered by groups in complex environments. Efficacy is normally taken as the capability an agency has to organize and implement a series of actions to produce given attainments or performances (Bandura, 1977; Wood \& Bandura, 1989). This capability is influenced by the capacity of operative intelligence to generate coherence, and (as noted by Bandura, 2005: 316) an agency's interactive, coordinative, and synergistic dynamics.

An agency is interactive with an environment that may include other agencies, as illustrated in Figure 1. It functions through behavioural intelligence, as represented through its overt actions (Ang, Van Dyne, Koh, Ng, Templer, Tay \& Chandrasekar, 2007: 6). This is constituted as a "structural coupling" (Maturana and Varela, 1987), meaning that there is an epistemic relationship between two "living system" coupled entities, which create an interactive connection between their past, present and future histories.

\section{The Dynamic Nature of the Cultural Trait}

The term trait as used here refers to the preferential variables of an agency that are formative in defining its functional nature. The traits are dichotomous, and may take one of two bi-polar qualitative values (called enantiomers) which orientate the agency in the way that it processes information and develops, and which ultimately creates a penchant towards particular forms of decision and policy making and behaviour. For Van Egeren (2009) and Davis (2000), such traits operate as fundamental control and characterising function. There are 5 traits: combinations of the enantiomers of 3 normative personality traits create personality types; two traits are part of the personality environment: cultural and social. Combinations of the 5 traits create agency types. Agency cultural orientation controls what is culturally legitimate in the agency, while social orientation controls how the agency reacts to the perceived needs of what it identifies as its environment, including others. To understand the cultural dynamics of traits one has to refer to the important auxiliary function of the alternate poles of the traits (Jung, 1971; Blutner \& Hochnadel, 2010). Auxiliary processes between the alternate poles result from the necessity of a mix of values that comes from the orientations towards the alternate poles of a trait. The alternate poles have an essential and indispensable auxiliary function for the existence and survival of a system: Embeddedness secures social coherence, 
but too much of embeddedness would impede innovation; intellectual autonomy would strongly foster innovation, but impede coherence of a social whole; too much of mastery would impede the social fabric of a society, too much of harmony would impede achievement orientation; too much of hierarchy would impede loyalty of subordinates, too much of egalitarianism would impede consistent action of a social whole. In the following we will more closely investigate into the 'inbuilt' dynamics of the cultural trait (Sorokin 1937-42), and refer to the long term swings between sensate and ideational cultures, with a balanced intermediate state of a so-called idealistic, or integral culture. Similar alternate functions apply to Patterning and Dramatising. Patterning is curiosity about the social environment and collects information. The auxiliary functions of Patterning and Dramatising in an Idealistic culture are that Patterning collects and controls the validity of information about the outside world, and Dramatising is the art of telling the outside world that the agency does have collected and weighted appropriate information and thus has the knowledge, means and abilities to do something about a specific situation.

Cultural orientation is core to the agency, and its very nature draws on the dynamic theory of Sorokin (1937-42). This begins with the realisation that culture may be seen as being constituted through the shared norms, values, beliefs and assumptions, and the behaviour and artefacts that express these orientations - including symbols, rituals, stories, and language; norms and understanding about the nature and identity of the social entity, the way work is done, the value and possibility of changing or innovating, relations between lower and higher ranks, the nature of the environment (Yolles, 2006; Williams et al, 1993). All durable societies have a culture. This is explained by Schaller, Conway \& Crandall (2008) when they refer to Sumner's realization that culture results from the frequent repetition of petty acts that result in what he calls folkways. They further note that these cultural folkways "are not creations of human purpose and wit" but are instead "products of natural forces which men unconsciously set in operation" (Sumner, 1906: 4) and which develop through fundamental psychological processes that govern the thoughts and actions of individuals.

Culturally based social groups (socio-cultures) are not static entities that are just shaped simply in reaction to external forces. The reason (Kemp, 1997) is that socio-cultures are dynamic systems, constantly in a state of change generated by the properties within the system. In other words human cultures do not 'change', but are rather always in a 'state of change'. They form historically not as discrete entities, but through continuous development. Thus, cultures can be defined less for what they are now, and more for where they are coming from and where they are going.

An explanation for change in the complex socio-cultural system has been given by Sorokin (1937-42) through his Principle of Immanent Change. This tells how cultures change not just as a response to the external needs of human society, but through something that occurs within the process itself. This principle states that a durable social system changes by virtue of its own forces and properties, and it cannot help changing even if all external conditions are constant. A socio-cultural system satisfying this principle generates consequences which are "not the results of the external factors to the system, but the consequences of the existence of the system and of its activities.

\section{Traits, Agency Types, and Immanent Dynamics}

Following Yolles \& Fink (2013) it is possible to establish the normative personality traits (Table 1). These have an epistemological basis, and measures of types can be determined 
empirically from the assessment of an agency's enduring cultural values. The traits of the normative personality interact together to form mindsets as shown in Table 2, which by themselves fall broadly into the two classes of Individualism and Collectivism. Given that an agency is culturally stable, a Sensate cultural orientation will result in Individualist perspective and attitudes and a Dramatising social orientation, while an Ideational cultural orientation will result in Collectivist perspective and attitudes and a Patterning social orientation. In this way different patterns of behaviour can be anticipated.

As part of its immanent dynamics, an agency self-develops. This necessarily centres on the cultural dynamics of the agency which is an attractor for the personality and social orientation traits, and hence on the creation of a potential for specific patterns of behaviour. This is because the cultural trait creates a field of attraction that the agency's personality and social orientation responds to in specific ways as long as no pathologies interfere with that field. Now, the immanent dynamics is represented in an agency by the values that its traits take. In principle this lies on a continuum between the two extreme polar enantiomers, but in practice it may be that this range is constrained to a more narrow determinable set.

Nieli (2012) looks at the changes in cultural dynamic shown in Sorokin's (1962) original study. As a result he generates a number of phases that appear between Ideational and Sensate cultural states. These are shown in Tables 3.1, 3.2 and 3.3. Table 3.1 illustrates three phases, starting from a normal Ideational state, which then declines as two post-normal phases develop. As this occurs there will be some growth in the polar opposite Sensate enantiomer. Table 3.2 consists of three phases representing movement away from a normal Idealistic cultural state, resulting in two progressively post-normal phases as the sensate enantiomer dominance increasingly Sensate decays, with the likely growth of Ideationalism. Table 3.3 consists of one phase that constitutes a stable Idealistic cultural state, but no additional phases have been noted by Nieli for this. The movement from a predominantly Ideational to a predominantly Sensate state can normally occur through the development of Idealistic culture, as is the case with a movement from predominantly Sensate to Ideational culture. However, conditions may occur such that Idealistic culture may not materialise.

These phases can be set up across the dynamics of change that run from normal to postnormal with increased uncertainty, to chaos, and perhaps on to transformation. This is illustrated in Figure 3 with explanation of the terms in Table 4 (adapted from Yolles, 2010). These phase shifts are consistent with a movement into cultural instability that occurs with both growth and decline of a social system (White, Tambayong \& Kejžar, 2008). There are two forms of growth and decline: incremental and transformative. Growth and decline will normally occur together, arising from the inherent dynamic interaction between the trait enantiomers. When culture is stable this refers to the attractor cultural trait, but when it is unstable and thus is therefore effectively disconnected from the rest of the agency, it also applies to the personality traits. In crisis, incremental changes can shift to transformative change, and when decline is more significant than growth, death results, while if growth dominates the result of growth is transformation. When growth and decline are unable to achieve any form of significant ascendency, this would likely mean the agency continues as it was before.

\begin{tabular}{|c|l|l|}
\hline Trait & Enantiomer & Nature \\
\hline Cognitive & $\begin{array}{l}\text { Intellectual } \\
\text { Autonomy }\end{array}$ & $\begin{array}{l}\text { People seen as autonomous, bounded entities who should find meaning in their own uniqueness and who } \\
\text { are encouraged to express their internal attributes (preferences, traits, feelings and motives). Intellectual }\end{array}$ \\
\cline { 2 - 3 }
\end{tabular}




\begin{tabular}{|c|c|c|}
\hline & & autonomy encourages individuals to pursue their own ideas and intellectual directions independently. \\
\hline & Embeddedness & $\begin{array}{l}\text { People are viewed as entities embedded in the plural agency. Meaning in life comes through social } \\
\text { relationships, identifying with the group, participating in its shared way of life and striving towards its } \\
\text { shared goals. Such values as social order, respect for tradition, security and wisdom are especially } \\
\text { important. Embedded cultures emphasise maintaining the status quo and restraining actions or inclinations } \\
\text { that might disrupt in-group solidarity or the traditional order. Embrace responsibility and duty and commit } \\
\text { to shared goals. Connected with Transactional scripting that constitutes simple repetition and sameness. }\end{array}$ \\
\hline \multirow[t]{2}{*}{ Figurative } & $\begin{array}{l}\text { Mastery \& } \\
\text { Affective } \\
\text { Autonomy }\end{array}$ & $\begin{array}{l}\text { Encourages active self-assertion to attain group or personal goals and to master, direct and change the } \\
\text { natural and social environment. It is basically monistic in nature. The affective autonomy aspect that is } \\
\text { encouraged is the pursuit of affectively positive experiences. It encourages individuals to pursue } \\
\text { affectively positive experience for themselves. Likely to treat others as independent actors with their own } \\
\text { interests, preferences, abilities and allegiances. Others need autonomy to self-develop own ideas. }\end{array}$ \\
\hline & Harmony & $\begin{array}{l}\text { Trying to understand and appreciate rather than to direct or exploit. This orientation emphasizes the goals } \\
\text { 'unity with nature', 'protecting the environment', and 'world at peace'. It is basically pluralistic in nature. }\end{array}$ \\
\hline \multirow[t]{2}{*}{ Operative } & Hierarchy & $\begin{array}{l}\text { People are socialized to take the hierarchical distribution of roles for granted and to comply with the } \\
\text { obligations and rules attached to their roles. In hierarchical cultures, organizations are more likely to } \\
\text { construct a chain of authority in which all are assigned well-defined roles. There is an expectation that } \\
\text { individuals operate for the benefit of the social organization. Sees the unequal distribution of power, roles } \\
\text { and resources as legitimate. This has an implicit connection with power and power processes. }\end{array}$ \\
\hline & Egalitarianism & $\begin{array}{l}\text { Seeks to induce people to recognize one another as moral equals who share basic interests as human } \\
\text { beings. People are socialized to internalize a commitment to co-operate and to feel concern for everyone's } \\
\text { welfare. They are expected to act for others' benefit as a matter of choice. Organisations are built on co- } \\
\text { operative negotiation among employees and management. This has an implicit connection with service to } \\
\text { the agency. }\end{array}$ \\
\hline
\end{tabular}

Table 1: Summary of the Traits and their Bi-Polar Enantiomers for an Agency

Sources: Sorokin (1962), Sagiv and Schwartz (2007).

\begin{tabular}{|c|c|c|c|}
\hline \multicolumn{2}{|l|}{ Pole 1 - Individualism Type } & \multicolumn{2}{|l|}{ Pole 2 - Collectivism Type } \\
\hline Mastery Individualism & Enantiomers & Harmony Collectivism & Enantiomers \\
\hline $\begin{array}{l}\text { 1: HI } \\
\text { Hierarchical } \\
\text { Individualism }\end{array}$ & $\begin{array}{l}\text { Intellectual Autonomy } \\
\text { Mastery \& Affective } \\
\text { Autonomy } \\
\text { Hierarchy }\end{array}$ & $\begin{array}{l}\text { 8: } \boldsymbol{E C} \\
\text { Egalitarian Collectivism } \\
\text { [Mindscape } \boldsymbol{S} \\
\text { Social/ Reformer] }\end{array}$ & $\begin{array}{l}\text { Embeddedness } \\
\text { Harmony } \\
\text { Egalitarianism }\end{array}$ \\
\hline $\begin{array}{l}\text { 2: } \boldsymbol{E I} \\
\text { Egalitarian Individualism } \\
\text { [Mindscape I } \\
\text { Independent/ Prince] }\end{array}$ & $\begin{array}{l}\text { Intellectual Autonomy } \\
\text { Mastery \& Affective } \\
\text { Autonomy } \\
\text { Egalitarianism }\end{array}$ & $\begin{array}{l}\text { 7: HC } \\
\text { Hierarchical } \\
\text { Collectivism }\end{array}$ & $\begin{array}{l}\text { Embeddedness } \\
\text { Harmony } \\
\text { Hierarchy }\end{array}$ \\
\hline $\begin{array}{l}\text { Harmony Individualism } \\
=>\text { Synergism }\end{array}$ & & $\begin{array}{l}\text { Mastery Collectivism } \\
=>\text { Populism }\end{array}$ & \\
\hline $\begin{array}{l}\text { 3: HS } \\
\text { Hierarchic Synergism }\end{array}$ & $\begin{array}{l}\text { Intellectual Autonomy } \\
\text { Harmony } \\
\text { Hierarchy }\end{array}$ & $\begin{array}{l}\text { 6: } E P \\
\text { Egalitarian Populism }\end{array}$ & $\begin{array}{l}\text { Embeddedness } \\
\text { Mastery \& Affective } \\
\text { Autonomy } \\
\text { Egalitarianism }\end{array}$ \\
\hline $\begin{array}{l}\mathbf{E} \boldsymbol{E S} \\
\text { Egalitarian Synergism } \\
\text { [Mindscape } \boldsymbol{G} \\
\text { Generative/Revolutionary] }\end{array}$ & $\begin{array}{l}\text { Intellectual Autonomy } \\
\text { Harmony } \\
\text { Egalitarianism }\end{array}$ & $\begin{array}{l}\text { 5: HP } \\
\text { Hierarchical Populism } \\
\text { [Mindscape: } \text { H: } \\
\text { Hierarchical/ Bureaucrat] }\end{array}$ & $\begin{array}{l}\text { Embeddedness } \\
\text { Mastery \& Affective } \\
\text { Autonomy } \\
\text { Hierarchy }\end{array}$ \\
\hline
\end{tabular}

Table 2: Contrasting Pairs of Mindsets and Reference to the 4 Maruyama-Mindscapes

(Source: Yolles and Fink, 2013; Maruyama 1988, 2001)

\begin{tabular}{|c|c|c|c|c|}
\hline Stable Ideational Culture & \multicolumn{4}{l|}{} \\
\hline Phases of Cycle & Explanation & Attractor for & Mindset & Individualism- \\
\hline
\end{tabular}




\begin{tabular}{|c|c|c|c|c|}
\hline & & $\begin{array}{c}\text { Personality } \\
\text { Traits }\end{array}$ & $\begin{array}{c}\text { Type } \\
\text { Attraction }\end{array}$ & $\begin{array}{c}\text { Collectivism } \\
\text { Type }\end{array}$ \\
\hline Ascetical & $\begin{array}{l}\text { An agency puts emphasis on disengaging any energies } \\
\text { and attachments from bodily pleasures and from the great } \\
\text { temporal flux of the sensory order so that they might } \\
\text { draw nearer to a super-sensible reality }\end{array}$ & $\begin{array}{l}\text { Intellectual } \\
\text { Autonomy, } \\
\text { Harmony, and } \\
\text { Egalitarianism }\end{array}$ & 4 & $\begin{array}{l}\text { Ideational } \\
\text { Individualism }\end{array}$ \\
\hline \multicolumn{5}{|c|}{ Entry to post-Ideational decline towards cultural instability } \\
\hline Active & $\begin{array}{l}\text { There is an emphasis on the control of human desires, a } \\
\text { condition that is disengaged from the social environment } \\
\text { which it perceives to be corrupt. It is proselytizing and } \\
\text { transformative seeking to remake the unredeemed world } \\
\text { according to the tenets of the ideational world-view }\end{array}$ & $\begin{array}{l}\text { Embeddedness } \\
\text { Harmony, and } \\
\text { Egalitarianism }\end{array}$ & 8 & $\begin{array}{l}\text { Ideational } \\
\text { Collectivism, }\end{array}$ \\
\hline Fideistic & $\begin{array}{l}\text { A late stage of Ideational culture where intuition and the } \\
\text { on-going testimony of the mystics, prophets, and saints is } \\
\text { replaced by a blind and desperate "will-to-believe" on the } \\
\text { part of a people who have lost any kind of direct contact } \\
\text { with the supra-conscious. }\end{array}$ & $\begin{array}{l}\text { Embeddedness } \\
\text { Harmony, and } \\
\text { Hierarchy }\end{array}$ & 7 & $\begin{array}{l}\text { Ideational } \\
\text { Collectivism, }\end{array}$ \\
\hline
\end{tabular}

Table 3.1: Main characteristics of Ideational culture and its decline (adapted from: Sorokin, 1942; Nieli, 2012)

\begin{tabular}{|c|c|c|c|c|}
\hline \multicolumn{5}{|c|}{ Stable Sensate culture } \\
\hline Phases of Cycle & Explanation & $\begin{array}{c}\text { Attractor for } \\
\text { Personality } \\
\text { Traits } \\
\end{array}$ & $\begin{array}{c}\text { Mindset } \\
\text { Type } \\
\text { Attraction } \\
\end{array}$ & $\begin{array}{c}\text { Individualism- } \\
\text { Collectivism } \\
\text { Type } \\
\end{array}$ \\
\hline Active & $\begin{array}{l}\text { Action to transform the external environment to satisfy an } \\
\text { agency's needs and desires. Illustrations are the creation } \\
\text { of business empires, innovators in technology, political } \\
\text { organizers, pioneers in the wilderness and military } \\
\text { conquerors. }\end{array}$ & $\begin{array}{l}\text { Intellectual } \\
\text { Autonomy, } \\
\text { Mastery \& } \\
\text { Affective } \\
\text { Autonomy, } \\
\text { Egalitarianism }\end{array}$ & 2 & $\begin{array}{l}\text { Sensate } \\
\text { Individualism }\end{array}$ \\
\hline \multicolumn{5}{|c|}{ Entry to post-Sensate decline towards cultural instability } \\
\hline Passive & An agency focuses on self-gratification and enjoyment & $\begin{array}{l}\text { Intellectual } \\
\text { Autonomy, } \\
\text { Mastery \& } \\
\text { Affective } \\
\text { Autonomy, } \\
\text { Hierarchy }\end{array}$ & 1 & $\begin{array}{l}\text { Sensate } \\
\text { Individualism, }\end{array}$ \\
\hline Cynical & $\begin{array}{l}\text { Agencies maintain an advanced state of nihilistic } \\
\text { decadence (moral degeneration or decay through total } \\
\text { rejection of established laws and institutions), where the } \\
\text { Sensate ethos itself undermines its own claims to truth, } \\
\text { and produces insincere hedonists (pleasure/ happiness is } \\
\text { the highest good) and social climbers without conviction } \\
\text { or redeeming merit. }\end{array}$ & $\begin{array}{l}\text { Embeddedness } \\
\text { Mastery \& } \\
\text { Affective } \\
\text { Autonomy } \\
\text { Hierarchy }\end{array}$ & 5 & $\begin{array}{l}\text { Sensate } \\
\text { Collectivism }\end{array}$ \\
\hline
\end{tabular}

Table 3.2: Main characteristics of Sensate culture and its decline (adapted from: Sorokin, 1942; Nieli, 2012)

\begin{tabular}{|l|l|l|c|c|}
\hline \multicolumn{1}{|l|}{ Stable Idealistic Culture } & $\begin{array}{c}\text { Attractor for } \\
\text { Phases of Cycle }\end{array}$ & $\begin{array}{c}\text { Mindset } \\
\text { Traits }\end{array}$ & $\begin{array}{c}\text { Individualism- } \\
\text { Typectivaction } \\
\text { Collectivism } \\
\text { Type }\end{array}$ \\
\hline & \multicolumn{1}{|c|}{ Explanation } & & \\
\hline $\begin{array}{l}\text { Idealistic } \\
\text { Integrative or } \\
\text { Integral) }\end{array}$ & $\begin{array}{l}\text { Super-sensory and creative aspects of life balanced by } \\
\text { sensory and material aspects, enabling internal } \\
\text { orientations that develop being to be accompanied by } \\
\text { externally directed interests and instrumental activities } \\
\text { that relate to becoming. }\end{array}$ & $\begin{array}{l}\text { Eastery \& } \\
\text { Affective } \\
\text { Autonomy } \\
\text { Egalitarianism }\end{array}$ & 6 & Sensate \\
Collectivism & \\
\end{tabular}

Table 3.3 Main characteristics of Idealistic culture (adapted from: Sorokin, 1942; Nieli, 2012) 


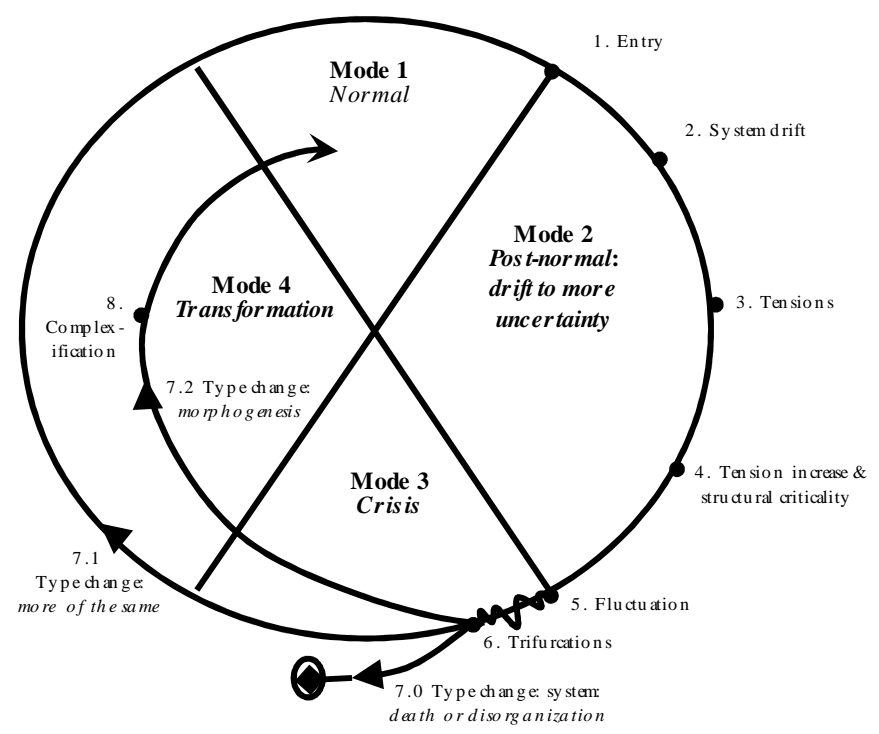

Figure 3: Dynamics of a system out of stability, where trifurcation occurs with instability

\begin{tabular}{|c|c|c|}
\hline Mode of Science & Step & Movement towards evolution \\
\hline Normal & 1. Stability & $\begin{array}{l}\text { The system exists with a stable system, though during normal development } \\
\text { the base may change its form incrmentally. }\end{array}$ \\
\hline $\begin{array}{l}\text { Post-normal } \\
\text { (uncertainty drift) }\end{array}$ & $\begin{array}{ll}\text { 2. } & \text { System drift } \\
\text { 3. } & \text { Tension } \\
\text { development } \\
\text { 4. } & \text { Tension increase and } \\
\text { structural criticality }\end{array}$ & $\begin{array}{l}\text { Dissipative processes are introduced as the system become incapable of } \\
\text { delivering promises. In a complex application domain, drift enables } \\
\text { unexpressed potentials to be actualized. The drift takes the system away } \\
\text { from its stable position and gives rise to tensions between its ability to } \\
\text { explain and predict, and questions about its methods in relation to } \\
\text { observations. }\end{array}$ \\
\hline Crisis & $\begin{array}{l}\text { 5. } \\
\text { Fluctuations } \\
\\
\text { 6. } \quad \text { Trifurcations } \\
\text { 7.0 Systemic death } \\
\text { 7.1 Type } 1 \text { change }\end{array}$ & $\begin{array}{l}\text { The tensions, following the tropic drift that moved the paradigm away from } \\
\text { its stable normal mode, are leading it to structural criticality. If the } \\
\text { system loses robustness, fluctuations are amplified. Fluctuations occur } \\
\text { internally, or in the environment as noise. Through amplification of } \\
\text { fluctuations due to tensions following uncertainty drift, a discontinuity } \\
\text { occurs in the causal sequence of events. This likely will be accompanied } \\
\text { by debates that centre on confling perspectives. } \\
\text { When trifurcations occur the system is able to take a variety of possible } \\
\text { paths towards its future. At this point three options are possible. In type } \\
7.0 \text {, decay represents a process of disorganization, regression, or } \\
\text { extinction of the system. In type } 7.1 \text { the process of change begins with } \\
\text { "more of the same" small changes that maintain its current state but do } \\
\text { not resolve issues. This process of iteration, however, will often result in } \\
\text { system complexification. }\end{array}$ \\
\hline Transformation & 7.2 Type 2 change & $\begin{array}{l}\text { In type } 2 \text { change, metamorphosis occurs through emergence that occurs } \\
\text { with stable states of a system, due to processes of decline and growth, } \\
\text { and these are amplified within its critical structure. This is referred to as } \\
\text { morphogenic change, occurring through amplification and } \\
\text { differentiation. It is a relational process that develops in the system } \\
\text { through positive and negative feedback, and integration. }\end{array}$ \\
\hline
\end{tabular}

Table 4: Explanation for the terms in the system dynamics (Figure 3).

Under normal stable cultural condition the cultural phases are attractors for personality and social orientation traits, and we have assigned the likely traits and related personality mindset types to these attractors. In addition we have also assigned forms of Individualism and Collectivism in Table 3.1-3.3. Here, Sensate Collectivism and Individualism refer to material attributes of Individualism and Collectivism, while their Ideational qualifier refer to more cognitive interpretations of Individualism and Collectivism that are not connected with the material. 
In Tables 3.1-3.3 we have deduced mindsets for each of Nieli's phases of cultural change to Schwartz' set of value dimensions. However, outside stable cultural values of Idealistic, Sensate and Idealistic, these mindsets should be currently seen as a deducible guestimate, one reason being that when cultural instability arises personality inertia may take over temporarily until the personality traits determine their own internal dynamics. The model in Figure 1 arises from a recursive system since the generic living system model was used recursively to generate a structure for personality. So the generic properties of one recursion can typically be applied to another. Hence, using this principle of recursion, when the cultural trait becomes disconnected from the agency, the cognitive trait substitutes its role and becomes an attractor for the rest of the personality. Thus, if the cognitive trait takes the value of an Individualist oriented enantiomer (i.e., Intellectual Autonomy), then it will be an attractor for the other traits of the personality, which will move towards related values. The result to be expected in this case would be the type 1 mindset: Hierarchical Individualism. A relatively similar situation applies if it would take on a Collectivist orientated enantiomer that is a type 8 mindset: Egalitarian Collectivism. However, there is no attraction imperative for the social orientation trait, because its trait values could emerge from the arbitrary causes of the agencies' repeated interaction with segments of its operative environment. As a result, personality and social orientation may take conflicting values, resulting in dysfunction.

These considerations provide improved understanding of the way in which cultural attractors can influence personality mindsets and social orientations, thereby enabling the anticipation of patterns of behaviour. A further essential need of this research will be to explore the pathologies that develop in an agency, how these point the agency towards determinable dysfunctions, and how this may lead to the development of diagnostic approaches.

\section{Conclusion}

Our primary interest in this paper has been in plural agencies. We have modelled them generically as a "living system", having an indirectly observable culture and normative personality from which, using traits, one can in principle to anticipate their patterns of behaviour given a known context. We have shown that from a number of core principles, it is possible to generate traits that coalesce into personality mindset types from which patterns of behaviour can be anticipated. These operate through intelligences that are susceptible to pathologies, from which agency dysfunction can develop. In principle such dysfunctions can be easily diagnosed and corrected.

\section{References}

Ang, S., Van Dyne, L., Koh, C.K.S., Ng, K.Y., Templer, K.J., Tay, C., \& Chandrasekar, N.A., 2007, Cultural intelligence: Its measurement and effects on cultural judgment and decision making, cultural adaptation, and task performance, Management and Organization Review, 3: 335-371.

Bandura, A. 1977. Self-efficacy: Toward a unifying theory of behavioral change. Psychological Review, 84: 191-215.

Bandura, A., 2005, Guide for constructing self-efficacy scales, in F. Pajares \& T. Urdan (Eds.), Self-efficacy beliefs of adolescents (pp.1-43), Greenwich, CT, Information Age Publishing.

Blutner, R. \& Hochnadel, E., 2010, Two qubits for C.G. Jung's theory of personality, Cognitive Systems Research, 11 (3), p.243-259, Sep 2010 
Dempster, B. (1999). Post-normal science: Considerations from a poietic systems perspective. School of Planning, University of Waterloo, online publications, www.fes.uwaterloo.ca/u/mbldemps/pubs/futures1999/index.html, accessed, April 2008.

Eisenhardt, K.M. (1989). Agency Theory: An Assessment and Review, The Academy of Management Review, 14(1)57-74

Elkind, D., 1976, Child Development and Education, www.scribd.com/doc/5079000/childdevelkind, accessed May 2013.

Fink, G., Dauber, D., and Yolles, M., 2012, Understanding organizational culture as a trait theory, European International Management, 6(2) pp. 199 - 220.

Fleishman, E. A., Constanza, D. P., \& Marshall-Mies J., 1999, Abilities, In: N. G. Peterson, M. D. Mumford, W. C. Borman, R. P. Jeanneret \& E. A. Fleishman (Eds), An Occupational Information System for the 21st Century: The Development of ONET, Washington, DC: American Psychological Association.

Guzzo, R. A., Yost, P. R., Campbell, R. J., \& Shea, G. P. 1993. Potency in groups: Articulating a construct. British Journal of Social Psychology, 32: 87-106.

Jung, C., 1971, Psychological types (H. G. Baynes, Trans., revision by R. F. C. Hull), The Collected Works of C. G. Jung (Vol. 6), Princeton, NJ: Princeton University Press, (Original work published 1921).

Kemp, G., 1997, Cultural Implicit Conflict: A Re-Examination of Sorokin's Socio-Cultural Dynamics, Journal of Conflict Processes 3(1)15, 24.

L'Abate, 2005, Personality in Intimate Relationships Socialization and Psychopathology, Springer: New York.

Lindsley, D., Brass, D.J., Thomas, J.B., 1995, Efficacy-Performance Spirals: A Multilevel perspective, Academy of Management Review, 20(3)645-678.

Maruyama, M., 1974, Hierarchists, Individualists and Mutualists, Futures, 6, 103-113.

Maruyama, M., 1988, Dynamics Among Business Practice, Aesthetics, Science, Politics and Religion, Cultural Dynamics, 1; 309,

Maruyama M., 2001, Individual Types: Subcultural or Transcultural, The General Psychologist, 36 (3): 64-67.

Maturana, H.R., Varela, F.J., 1987, The Tree of Knowledge. Shambhala, London.

Mayer, J. D. (2005). A tale of two visions: Can a new view of personality help integrate psychology? American Psychologist, 60, 294-307.

Montangero, J., \& Maurice-Naville, D. 1997. Piaget, or The Advance of Knowledge: An Overview and Glossary. Lawrence Erlbaum Associates, Mahwah, NJ.

Mroczek, D.K., Little, T.D., 2006, Handbook of personality development, Lawrence Erlbaum Associates, Mahwah, NJ.

Nieli, R., 2012, Critic of the Sensate Culture: Rediscovering the Genius of Pitirim Sorokin, First Principles, Intercollegiate Studies Institute, www.firstprinciplesjournal.com/articles.aspx $?$ article $=1555 \&$ theme $=$ home $\&$ page $=1 \&$ loc $=b$ \&type $=\mathrm{cttf}$, accessed June 2013.

Piaget, J. (1963, 2001). The psychology of intelligence. New York: Routledge.

Piaget, J., 1977, The Development of Thought: Equilibration of Cognitive Structures, Viking, New York.

Piaget, J., 1950, The Psychology of Intelligence, Harcourt and Brace, New York; Republished in 1972 by Totowa, NJ: Littlefield Adams.

Piaget, J. 1950. The Psychology of Intelligence. New York: Harcourt and Brace.

Piaget, J., \& Inhelder, B. 1969. The psychology of the child. New York: Basic Books.

Plucker, J., 2012, Human Intelligence, www.indiana.edu/ intell/piaget.shtml, accessed May, 2013. 
Sagiv, L., Schwartz, S.H., 2007, Cultural values in organisations: insights for Europe, European J. International Management, 1(3)167,190,

Schaller, M., Conway, G.C. Crandall, C., 2008, The Psychological Foundations of Culture: An Introduction, Lawrence Erlbaum Associates. Inc.

Schoenfeld, A.H., 1986, What's all the fuss about metacognition? In Schoenfefeld, A.H.,

(Ed), Cognitive Science and mathematical education, (pp.189-215), Hillside, N.J.

Shotwell, J.M., Wolf, D., Gardner, H. (1980). Styles of Achievement in Early Symbol Use, In

Brandes, F., (ed), Language, Thought, and Culture, pp175-199, Academic Press, N.Y.

Schwarz, E., 1997, Towards a Holistic Cybernetics: From Science through Epistemology to Being, Cybernetics and Human Knowing, Vol, 4, No, 1, pp17-50

Schwarz, E., 2003, Is Consciousness Reality or Illusion? A Non-Dualist Interpretation of Consciousness, Computing Anticipatory Systems: CASYS'03 - Sixth International Conference, 11-16 August, Liege, Belgium.

Sorokin, P., 1962, Social and Cultural Dynamics, in 4 volumes, Bedminster Press, New York, Originally published in 1937-1942 by the Amer Book Co., N.Y., USA.

Sorokin, P., 1937-42, Social and Cultural Dynamics, in 4 volumes, Amer, Book, Co: N.Y.

Sumner, W. G. (1906). Folkways. New York: Ginn

Tognetti, S.S. (1999). Science in a double-bind: Gregory Bateson and the origins of postnormal science, Futures 31, 689-703. See www.sylviatognetti.org/data/tognetti1999.pdf, accessed June 2008.

Van Egeren, L.F., 2009, A Cybernetic Model of Global Personality Traits, Personal Social Psychology Review, 13(2)92-108,

Williams, A., Dobson, P., Walters, M., 1993, Changing Culture: New organisational appropaches, Institute of Personnel Management, London,

Williams, B., Imam, I., 2006, Systems Concepts in Evaluation: An Expert Anthology, American Evaluation Association, http://preval,org/files/Kellogg\%20enfoque\%20sistematico\%20en\%20evaluacion,pdf, accessed May, 2010.

White, D. R., L. Tambayong, and N. Kejžar, 2008, Oscillatory dynamics of city-size distributions in world historical systems. Chapter 9, In Globalization as Evolutionary Process: Modeling, Simulating, and Forecasting Global Change, edited by G. Modelski, T. Devezas and W. Thompson, 190-225. London: Routledge. See www.imbs.uci.edu/files/imbs/docs/technical/2007/MBS07_03.pdf, accessed May 2013.

Wood, R., Bandura, A. 1989. Impact of conceptions of ability on self-regulatory mechanisms and complex decision making. Journal of Personality and Social Psychology, 56: 407-415.

Yolles, M.I. (2006). Organizations as Complex Systems: an introduction to knowledge cybernetics, Information Age Publishing, Inc., Greenwich, CT.

Yolles, M.I., 2010, Exploring Complex Sociocultural Situations through Soft Operational Research. Pesqui. Oper., 30(2)345-370, www.scielo.br/scielo.php?pid=S0101$74382010000200006 \&$ script=sci_arttext

Yolles, M., Fink, G., Dauber, D., 2011,'Organisations as emergent normative personalities: part 1, the concepts, Kybernetes (5/6), 635 - 669

Yolles, M.I., Fink, G., 2013, An Introduction to Mindset Theory: part 1 The Fundamentals, Submitted to PSPR, http://papers.ssrn.com/sol3/papers.cfm?abstract_id=2272169.

\section{Notes}

\footnotetext{
${ }^{1}$ Autogenesis is a second order form of autopoiesis (Schwarz, 1997) that has a higher level of processes - that is meta-processes that may be represented for instance as guiding personality convictions, principle influences, or even spirit. It occurs when a selectable network of these meta-
} 
processes is able to project into the operative couple a set of espoused values as attitudes and mental schemas and operative personality patterns. In effect autogenesis defines the autonomous system through the creation of its own set of laws.

2 Autopoiesis (Schwarz, 1997; Maturana and Varela, 1987) explains how a "living system" selfproduces its core relational explanations of reality that influence behaviour. This defines for the personality system it's own boundaries relative to its environment, develops its own unifying operational code, implements its own programmes, reproduces its own elements in a closed circuit, obeys its own laws of behaviour, and potentially satisfies its own intentions (Jessup, 1990). It also self-produces the network of processes that enable it to produce its own personality components that exist in cognitive, figurative and operative bases. 
